\title{
Growth and Quality of Green Bean (Phaseolus vulgaris L.) under Foliar Application of Organic- Chelate Fertilizers
}

https://doi.org/10.1515/opag-2018-0015

received October 21, 2017; accepted March 19, 2018

\begin{abstract}
Organic-based chelate fertilizers can effectively improve nutrient uptake and use efficiency of plants. In the present study, foliar applications of three organicchelate fertilizers on green bean (Phaseolus vulgaris L.) plants were compared to soil application of a mix chemical fertilizer (NPK) under greenhouse conditions. The treatments were foliar application (six sprays at $0.2 \%$ concentration) of Biomin, Humifolin, DelfonPlus, a mixture of micro and macronutrients, soil application of chemical fertilizer (NPK $0.5 \mathrm{~g} . \mathrm{kg}^{-1}$ soil), and no fertilizer control. Foliar applications of organic-chelate fertilizers improved plant height, leaf area, shoot dry weight, leaf $\mathrm{N}$ and $\mathrm{K}$ concentration, pod number and pod yield compared to control plants. Pod soluble solids, vitamin C and total protein contents were significantly increased by foliar application of organic-chelate fertilizers. Soil applied NPK also improved green bean productivity compared to no fertilizer control. For most plant growth traits, there was no significant difference among the three organicchelates. Foliar application of the macro- micro- nutrient mixture was not able to enhance the same growth, yield and pod quality traits like organic-chelates. Therefore, application of nutrient elements in form of organic-chelate and particularly by foliar application can guarantee better green bean plant performance.
\end{abstract}

Keywords: Amino acid, biofortification, fertilization, foliar feeding, nutrient uptake, pod quality, protein, vegetable

\footnotetext{
*Corresponding author: Mohammad Kazem Souri, Dept of Horticultural Sciences, Tarbiat Modares University, Tehran-Iran,

E-mail:mk.souri@modares.ac.ir

Maryam Aslani, Dept of Horticultural Sciences, Tarbiat Modares University, Tehran-Iran
}

\section{Introduction}

Sustainable and environmental friendly production strategies are key principles that must be respected in short- and long-term practices in agricultural activities. Application of chemical fertilizers, in particular nitrogen (N) and iron ( $\mathrm{Fe}$ ) fertilizers have had significant effect on growth and yield improvement in many agricultural crops (Fernández and Ebert 2005). However, various challenges have emerged on plant, human and ecosystem health issues. Therefore, nutritional management of crops to achieve higher yield and quality, as well as to maintain or to improve soil fertility needs new strategies in fertilizer formulation and application techniques. These strategies must be also friendly to human and environmental health regulations (Souri, 2016).

In soil application, use efficiency of many fertilizers is relatively minor (Fernández and Ebert 2005; Ashraf and Foolad 2007; Ghasemi et al. 2013), particularly under dry climates with calcareous and saline soils (Marschner 2011; Souri et al. 2017). Improved soil application techniques such as deep banding placement and use of pellet or coated fertilizers, are suitable practices for increasing fertilizer use efficiency. Foliar feeding also represents a useful technique for mineral nutrition of plants (Fernández and Ebert 2005). However, all plant species may not have proper responses to foliar feeding (Fahimi et al. 2016), and it is generally considered as complementary to soil fertilizer application.

Recently released amino acid-based fertilizers, namely aminochelates, are especially formulated for foliar feeding (Ashmead 1986; Souri 2016); while their soil application also results in higher efficiency than general chemical fertilizers (Fahimi et al. 2016; Souri et al. 2017).

Organic-chelate fertilizers, based on their structure and formulations, may have many advantages over general chemical salt fertilizers including: higher uptake and efficiency rates (Ghasemi et al. 2012), no potential hazard of environmental pollution, better adaptation 
to plant growth and metabolism (Ghasemi et al. 2014), minimum precipitation and leaching (particularly using foliar feeding) (Ashmead 1986), no antagonist interaction with other nutrient elements, and increasing soil fertility (Souri 2016). Chelating nutrients in organic compounds such as amino acids are also suitable fertilizers in stressful climatic conditions (Ghasemi et al. 2014; Sadak et al. 2015). Application of aminochelate fertilizers in soil or particularly in foliar spray has generally less deteriorating effects on soil salinity or on unbalancing soil nutrients. In addition, it has been shown that application of aminochelates results in higher plant tolerance to salinity stress, in tomato (Lycopersicon esculentum Mill) (Ghasemi et al. 2014), faba bean (Vicia faba L.) (Sadak et al. 2015), strawberry (Fragaria $\times$ ananassa Duch.) (Keutgen and Pawelzik 2008) and wheat (Triticum aestivum L.) (AbdulQados 2009). Several studies have evaluated the effects of various commercial or lab-synthesized aminochelates on plants, and revealed that their application increased plant growth (Datir et al. 2012; Atilio and Causin 1996; Ghoname et al. 2012), biomass production (Ghasemi et al. 2012), marketable yield (Naseri et al. 2013; Fahimi et al. 2016; Souri et al. 2017), quality parameters (Fahimi et al. 2016; Ghasemi et al. 2012, 2013; Machado et al. 2008) and mineral composition (Garcia et al. 2011; Ghasemi et al. 2014). Foliar compared to soil application of organicchelate fertilizers of Humifolin and Biomin on cucumber plants (Cucumis sativus L.) showed that soil applied Humifolin, NPK and then Biomin, respectively, resulted in higher leaf SPAD index, number of lateral shoots, shoot fresh weight, percent of fruit dry weight and fruit soluble solids. Foliar application of Biomin at $0.2 \%$ concentration resulted in severe leaf chlorosis and significantly low plant growth and yield, while this problem was not observed in foliar application of Humifolin (Fahimi et al. 2016).

Green bean (Phaseolus vulgaris L.) is a worldwide vegetable crop cultivated in many parts of Iran particularly during summer season, and recently under protected greenhouse. It is relatively sensitive plant to calcareous soils, in which routine simple fertilizers can not fully recover nutrient deficiencies. Aminochelates are claimed to be more efficient as well as safer on environmental issues. Every year in Iran, a significant portion of potential yield of beans is lost due to lime-affected soils which are the dominant type of soil in many parts of the country. The cost of synthetic chelates is also very high and all farmers can not afford them, whereas recently developed organic chelates could be cheaper alternatives. Therefore, this study aimed to evaluate the effects of foliar applications of some organic-chelate fertilizers on growth, yield and quality of green bean plants.

\section{Material and methods}

\subsection{Experiment setup and treatments}

The experiment was conducted in 2013, under greenhouse conditions, and based on completely randomized design using 6 treatments and 4 replications. Black plastic pots of $10 \mathrm{~L}$ volume were used for plant cultivation. Each pot represented a replicate containing 4 plants. Bean seeds (10 seeds) were planted $1-2 \mathrm{~cm}$ in depth in the pot soil and then thinned to four plants per pot at three leaf stage. The average temperature during experiment was $25 \pm 5^{\circ} \mathrm{C}$, with a relative humidity of $65 \pm 5 \%$ and $400 \mu$ mole $\mathrm{m}^{-1} \mathrm{~s}^{-1}$ light intensity. Throughout the growing period, all pots and plants were treated the same regarding irrigation, as irrigation of pots was carried out based on $80 \%$ soil water holding capacity, by daily adding and adjusting the water content of pots using a precise balance.

The experiment consisted of various treatments as follow: Foliar applications of 1) Biomin (an aminochelate), 2) Humifolin (an organic acid chelate), 3) DelfonPlus (an amino acid compound), 4) A mixture of macromicronutrients, 5) Soil application of NPK, and 6) Control (without any fertilizer application).

\subsection{Soil preparation}

The experimental soil was collected from the agricultural field of Tarbiat Modares Uni., Tehran-Iran. Before application, the soil was passed through a $2 \mathrm{~mm}$ sieve, and then was analyzed in order to determine some physicochemical characteristics which are presented in Table 1.

Table 1: Properties of the soil used in the experiment

\begin{tabular}{|c|c|c|c|c|c|c|c|c|}
\hline Texture & $\mathrm{pH}$ & $\begin{array}{l}\mathrm{EC} \\
\left(\mathrm{ds} . \mathrm{m}^{-1}\right)\end{array}$ & $\begin{array}{l}\text { Total C } \\
\text { (\%) }\end{array}$ & $\begin{array}{l}\text { Total N } \\
\text { (\%) }\end{array}$ & $\begin{array}{l}P \\
\left(\mathrm{mg} \cdot \mathrm{kg}^{-1}\right)\end{array}$ & $\begin{array}{l}\mathrm{K} \\
\left(\mathrm{mg} \cdot \mathrm{kg}^{-1}\right)\end{array}$ & $\mathrm{Ca}\left(\mathrm{mg} \cdot \mathrm{kg}^{-1}\right)$ & $\mathrm{Mg}\left(\mathrm{mg} \cdot \mathrm{kg}^{-1}\right)$ \\
\hline Silty-Loam & 7.17 & 0.915 & 0.62 & 0.096 & 15.2 & 256 & 546 & 67 \\
\hline
\end{tabular}




\subsection{Elemental composition of fertilizers}

The elemental composition of the chelate fertilizers used in the experiment is presented as follow:

Biomin (amino acid based fertilizer; Arbico-Co, Texas, USA): consisted of macro and micro elements of $2 \%$ total $\mathrm{N}$ (volume) in form of amino acids (glycine), $2.5 \% \mathrm{Zn}, 1.5 \%$ $\mathrm{Mn}, 1 \% \mathrm{Fe}, 0.4 \% \mathrm{Mg}, 0.4 \% \mathrm{Cu}$, and $0.02 \%$ Mo.

Humifolin (humic acid based fertilizer; Tradecrop Co., Spain): consisted of $42 \%$ organic compounds (volume) including: 37\% fulvic and humic acids, $4 \%$ vitamins, $0.5 \% \mathrm{P}, 0.28 \% \mathrm{Fe}, 0.041 \% \mathrm{Zn}, 0.0035 \% \mathrm{Mn}, 0.0023 \% \mathrm{Cu}$, $0.0012 \% \mathrm{Mg}$, and $0.0012 \% \mathrm{~B}$.

DelfonPlus (only amino acid; Tradecrop Co., Spain): consisted of 37\% organic compounds (volume) including $24 \%$ free amino acids, $5 \% \mathrm{~N}$-protein ( $9 \%$ total $\mathrm{N}$ ).

Macro-micro nutrient mix was prepared in $100 \mathrm{~mL}$ (nearly similar to Biomin aminochelate formula) as follow: 5\% $\mathrm{N}, 2.5 \% \mathrm{Zn}, 2.5 \% \mathrm{Fe}, 2 \% \mathrm{Mn}, 0.5 \% \mathrm{Mg}$, and $0.5 \% \mathrm{Cu}$ in distilled water.

\subsection{Application of treatments}

Foliar applications of organic-chelates were done 6 times during the growth season, in a constant concentration of $0.2 \%$ for all fertilizers. Plants were sprayed at 6 o'clock in the morning using a portable sprayer, spraying the upper and lower leaves surface. The first spray was done at 4-leaf stage and the 5 sprays left were applied in 1 week intervals. During the experimental course, nearly a total amount of $50 \mathrm{~mL}$ solution was sprayed on each plant.

In NPK treatment, 0.5 g. $\mathrm{kg}^{-1}$ soil, from a 20:16:20 formulation, was mixed uniformly into the pot soil at the beginning of the experiment.

\subsection{Plant sampling and measurements}

Plants were harvested 8 weeks after germination. Various growth traits were measured during growing season, as well as at harvest time. The plant height $(\mathrm{cm})$ and pod length $(\mathrm{cm})$ were measured using a ruler, and SPAD value (chlorophyll index) of plant leaves was measured by a portable SPAD meter (Model SPAD-502 Plus, Illinois, USA), by average of 20-30 readings of all plant green leaves. The number of leaves of 4 plants in each pot was counted and the average plant leaf number was recorded. The plant stem diameter $(\mathrm{mm})$ at $1 \mathrm{~cm}$ above soil surface was measured by precise caliper (Mitutoyo,
Japan). The whole plant leaf area $\left(\mathrm{cm}^{2}\right)$ of 4 plants per pot was measured by leaf area meter (Model CI 202, Germany), and then calculated per plant. Green pods were harvested several times and the cumulative number of green pods and corresponding weights (pod yield) of four plants per pot were recorded and then calculated per plant. Average shoot dry weight ( $g$ ) of each plant was calculated after drying all 4 plants of each pot for $24 \mathrm{~h}$ in an oven at $65^{\circ} \mathrm{C}$. The percent of total soluble solids (TSS) was determined using a drop of pod extracted juice by refractometer (AtagoDR-AL-2001- Japan). The $\mathrm{pH}$ and titratable acidity of pods were determined using extraction of $5 \mathrm{~g}$ of fresh pods following the method of Fahimi et al. (2016). For determination of pod vitamin C, $5 \mathrm{~g}$ of pods from final harvest was crushed in a porcelain mortar with $10 \mathrm{~mL}$ of $6 \%$ metaphosphoric acid, then the juice was transferred into a $25 \mathrm{~mL}$ tube, and then centrifuged at $4000 \mathrm{rpm}$ for $10 \mathrm{~min}$. Five $\mathrm{mL}$ of the supernatant was transferred into an Erlenmeyer flask, and received $20 \mathrm{~mL}$ of metaphosphoric acid 3\%. The titration of the extract was done by 2,6-dichlorophenol indophenol until appearance of a rose-pink color. The amount of vitamin C (mg.100 ${ }^{-1} \mathrm{~g}$ FW) was calculated based on a standard curve of different L-ascorbic acid concentrations. Determination of pod protein content (\%) was performed using Bradford method (Bradford 1976). The pods were dried at $50^{\circ} \mathrm{C}$ for $48 \mathrm{~h}$, grinded and an amount of $0.3 \mathrm{~g}$ of dry powder was used for protein determination by wet digestion using salicylic acid and oxygen peroxide. Thereafter, each sample received $2.5 \mathrm{~mL}$ of sulphuric acid and was incubated at $280^{\circ} \mathrm{C}$ for 1 hour. The extract was used for $\mathrm{N}$ determination using Kjeldahl method (Velp, UDK 129). For calculation of percent of protein, the readings were multiplied by 6.25 . A similar procedure was used for leaf nitrogen determination by Kjeldahl method. Leaf potassium (K) concentration (\%) was measured after the ashing of $0.5 \mathrm{~g}$ leaf dry powder at $550^{\circ} \mathrm{C}$ for $6 \mathrm{~h}$ in a muffle furnace. The samples were then cooled and extracted 2 times using $2 \mathrm{~mL}$ of $1 / 3 \mathrm{HNO} 3$ $(\mathrm{v} / \mathrm{v})$ and heated to dryness. The ash was again dissolved in $2 \mathrm{~mL}$ of $1 / 3 \mathrm{HCl}(\mathrm{v} / \mathrm{v})$, and then diluted to $10 \mathrm{~mL}$ with hot deionised water. The amount of $\mathrm{K}$ in samples was measured by flame photometer, in which distilled water was used as blank, and different concentrations of potassium standard solution including $2.5,5$ and $10 \mathrm{ppm}$ $\mathrm{K}$ were prepared in $\mathrm{HCl}$, similar to extract samples, to draw the standard curve. The K concentration of samples was calculated using standard curve and dilution factors (Souri 2008). 


\subsection{Statistical analysis}

The data were analyzed using SPSS 16 and significant differences $(\mathrm{P}<0.05)$ among treatments were determined by ANOVA followed by Duncan Multiple Range test. The graphs were constructed using Microsoft EXCEL (Version 2007).

Ethical approval: The conducted research is not related to either human or animals use.

\section{Results and discussion}

\subsection{Growth parameters}

The results of the analysis of variance of the growth parameters, pod yield and pod quality traits are presented in Table 2. The effects of treatments for shoot dry weight, leaf $\mathrm{N}$ concentration, pod yield and pod length were significant at $\mathrm{P}=0.01$ level, and for plant height, stem diameter, leaf area, leaf K concentration, pod number, pod TSS, pod titratable acidity, pod vitamin $\mathrm{C}$ and pod protein content were significant at $\mathrm{P}=0.05$ level, respectively. The effect of treatments on leaf number, SPAD value and pod $\mathrm{pH}$ was not significant. Similar results were obtained in other studies (Ghasemi et al. 2012; Sadak et al. 2015; Souri et al.2017). The higher nutrients availability in fertilization treatments is probably involved in the increased growth traits in the present study. Plants can have various morphophysiological as well as biochemical responses to fertilization treatments (Marschner 2011); however, plants generally do not have similar response to fertilization in various traits.

The means of the vegetative parameters are presented in Table 3. The overall plant growth was improved by fertilizer applications. Foliar application of organicchelates, soil applied NPK and to a lesser extent macro and micronutrients mixture resulted in improved plant growth compared to control plants. For most of traits measured in the experiment there was no significant difference among the three organic-chelates; however, the DelfonPlus always showed higher records, except for stem diameter, where Humifolin showed the highest value. Soil applied NPK and foliar application of mix macro- micro- treatments resulted in same plant height, while foliar application of organic-chelates of Biomin, DelfonPlus and Humifolin resulted in significantly higher plant height than control plants. Plant stem diameter was also increased by foliar application of organic-chelates as well as by soil applied NPK (Table 3). The average of plant leaf area was significantly increased by organic-chelate fertilizers. All fertilizer treatments resulted in significant increase in plant leaf number (Table 3).

The beneficial effect of the three organic-chelates on many growth traits can be due to their higher uptake and translocation efficiency rates (Souri et al. 2017; Ghasemi et al. 2012, 2014). Plants can have higher nutrient uptake and efficiency by foliar spray than soil application. In addition, compared to soil application, foliar spray generally results in better fertilizer efficiency and improved plant growth and productivity (Fernández and Ebert 2005). Even under some critical climate conditions, foliar feeding represents the sole effective method to

Table 2: Analysis of variance of growth and yield related parameters of green bean plants

\begin{tabular}{|c|c|c|c|c|c|c|c|c|c|c|}
\hline \multicolumn{11}{|c|}{ Mean Squares } \\
\hline $\begin{array}{l}\text { Source of } \\
\text { variation }\end{array}$ & df & $\begin{array}{l}\text { Plant } \\
\text { height }\end{array}$ & $\begin{array}{l}\text { Stem } \\
\text { diameter }\end{array}$ & $\begin{array}{l}\text { Leaf } \\
\text { Area }\end{array}$ & $\begin{array}{l}\text { Leaf } \\
\text { number }\end{array}$ & $\begin{array}{l}\text { SPAD } \\
\text { value }\end{array}$ & $\begin{array}{l}\text { Shoot dry } \\
\text { weight }\end{array}$ & $\begin{array}{l}\text { Pod } \\
\text { yield }\end{array}$ & $\begin{array}{l}\text { Pod } \\
\text { number }\end{array}$ & $\begin{array}{l}\text { Pod } \\
\text { length }\end{array}$ \\
\hline Treatment & 5 & $3.964^{*}$ & $0.027^{*}$ & $8.552^{\star}$ & $8.675^{\mathrm{ns}}$ & $7.976^{\text {ns }}$ & $4.742^{\star *}$ & $22.59^{\star *}$ & $5.971^{*}$ & $4.604^{\star *}$ \\
\hline Error & 18 & 0.299 & 0.003 & 0.284 & 2.014 & 3.469 & 0.554 & 7.810 & 1.06 & 0.584 \\
\hline Total & 23 & & & & & & & & & \\
\hline
\end{tabular}

Continue of table 2

\begin{tabular}{|c|c|c|c|c|c|c|c|c|}
\hline \multicolumn{9}{|c|}{ Mean Squares } \\
\hline $\begin{array}{l}\text { Source of } \\
\text { variation }\end{array}$ & df & Pod TSS & Pod PH & Pod TA & $\begin{array}{l}\text { Pod } \\
\text { vitamin C }\end{array}$ & $\begin{array}{l}\text { Pod } \\
\text { protein }\end{array}$ & $\begin{array}{l}\text { Leaf } \mathrm{N} \\
\text { concentration }\end{array}$ & $\begin{array}{l}\text { Leaf } \mathrm{K} \\
\text { concentration }\end{array}$ \\
\hline Treatment & 5 & $0.367^{*}$ & $4.17^{\mathrm{ns}}$ & $7.541^{*}$ & $21.47^{*}$ & $19.732^{\star}$ & $1.363^{\star \star}$ & $0.572^{\star}$ \\
\hline Error & 18 & 1.216 & 0.537 & 1.033 & 0.729 & 2.638 & 2.746 & 0.963 \\
\hline Total & 23 & & & & & & & \\
\hline
\end{tabular}


overcome nutrient deficiencies or to increase nutrient concentrations in crop tissues (Souri 2016). Among the three organic-chelates, DelfonPlus recorded better growth, as the highest leaf area and shoot dry weight obtained in this treatment. The stimulatory effect of amino acids on plant growth has been also reported (Ghasemi et al. 2014;Ghoname et al. 2012). The semi-hormonal stimulation of applied organic chelates could have also contributed to improved vegetative growth of bean plants in the present study (Marschner 2011).

\subsection{Nutrient uptake}

Plants treated with foliar application of Biomin had significantly higher $\mathrm{N}$ concentration (Figure 1). Soil applied NPK, and foliar application of DelfonPlus and Humifolin also resulted in higher $\mathrm{N}$ concentration compared to control plants. A similar trend, but with a lesser extent, was observed for leaf $\mathrm{K}$ concentration (Figure 1), in which soil applied NPK showed the highest leaf $\mathrm{K}$ concentration. There was also significant increase in leaf $\mathrm{K}$ concentrations by foliar application of Biomin, Humifolin and DelfonPlus than the control plants (Figure 1). In all measured vegetative parameters including leaf nutrient concentration, the lowest value was recorded in control plants, followed by the foliar application of mix macro- micro- treatment (Table 3). Commercial organicchelate fertilizers are a source of various macro- and micronutrients, including $\mathrm{N}$, magnesium $(\mathrm{Mg}), \mathrm{P}, \mathrm{Fe}$, manganese $(\mathrm{Mn})$, zinc ( $\mathrm{Zn})$ and some other nutrients. Therefore, over their application plant tissue concentrations of those nutrients are expected to increase (Souri 2016). Nitrogen is the most important limiting nutrient element in many cultivation systems. It plays a key role in various metabolic processes including amino acid, peptide and

Table 3: Mean values $( \pm$ SD) of growth parameters of green bean plants treated with foliar applications of different organic chelates, a mix of nutrients and soil applied NPK under greenhouse conditions. In each column, means with at least one common letter are not significantly different $(P=0.05)$

\begin{tabular}{|c|c|c|c|c|c|}
\hline & $\begin{array}{l}\text { Plant height } \\
\text { (cm) }\end{array}$ & $\begin{array}{l}\text { Stem diameter } \\
(\mathrm{mm})\end{array}$ & $\begin{array}{l}\text { Average leaf area } \\
\left(\mathrm{cm}^{2}\right)\end{array}$ & Plant leaf number & $\begin{array}{l}\text { Shoot DW } \\
\text { (g) }\end{array}$ \\
\hline Control & $23.4 \pm 0.4^{b}$ & $0.32 \pm 0.03^{b}$ & $7.6 \pm 0.7^{c}$ & $7 \pm 1.3^{b}$ & $2.9 \pm 0.7^{c}$ \\
\hline NPK & $28.7 \pm 0.3^{a}$ & $0.43 \pm 0.02^{a}$ & $10.3 \pm 0.8^{b}$ & $10 \pm 2.4^{\mathrm{a}}$ & $4 \pm 0.9^{b}$ \\
\hline Biomin & $29.9 \pm 0.4^{\mathrm{a}}$ & $0.47 \pm 0.02^{\mathrm{a}}$ & $12.7 \pm 0.6^{\mathrm{a}}$ & $12 \pm 1.0^{\mathrm{a}}$ & $5.4 \pm 0.5^{\mathrm{a}}$ \\
\hline Humifolin & $28.8 \pm 0.6^{a}$ & $0.49 \pm 0.04^{\mathrm{a}}$ & $11.5 \pm 0.8^{a}$ & $11 \pm 1.3^{a}$ & $5.2 \pm 0.8^{\mathrm{a}}$ \\
\hline DelfonPlus & $31.8 \pm 0.9^{a}$ & $0.47 \pm 0.03^{a}$ & $12.9 \pm 0.7^{a}$ & $11 \pm 1.0^{\mathrm{a}}$ & $5.6 \pm 0.9^{a}$ \\
\hline Mix macro- micronutrient & $25.6 \pm 0.5^{b}$ & $0.33 \pm 0.02^{b}$ & $9.4 \pm 0.9^{b}$ & $10 \pm 1.1^{\mathrm{a}}$ & $3.4 \pm 0.3^{\mathrm{bc}}$ \\
\hline
\end{tabular}

-SD indicates standard deviation.

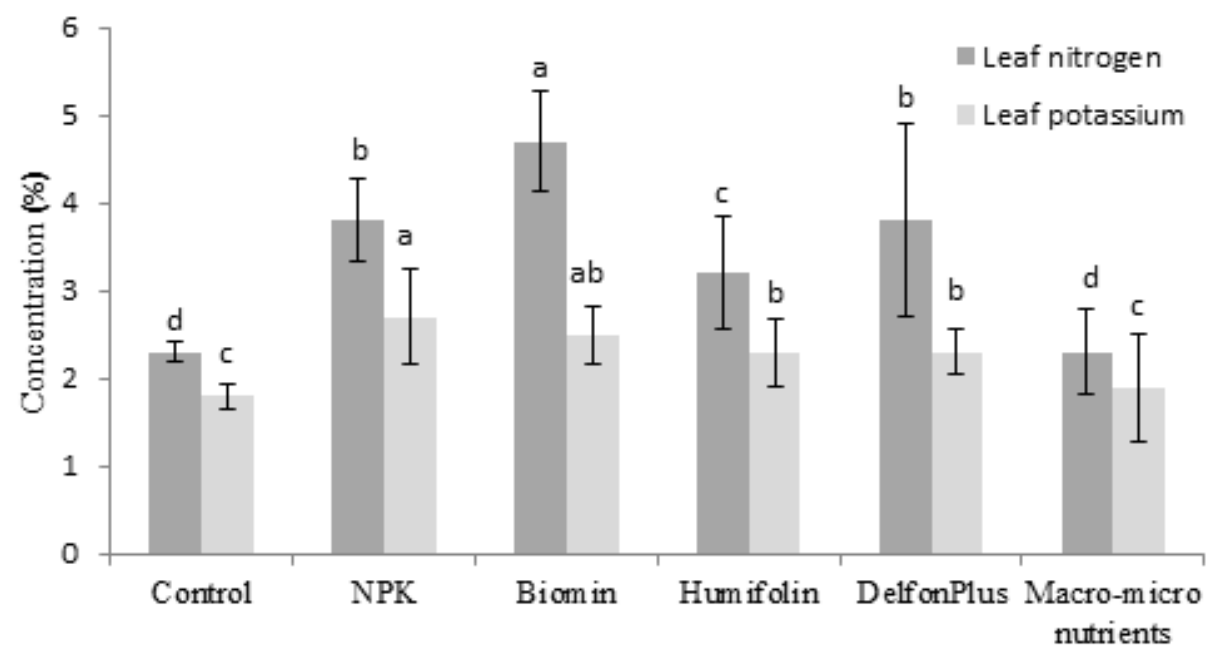

Figure 1: Mean values of leaf nitrogen $(\mathrm{N})$ and potassium $(\mathrm{K})$ concentration of green bean plants treated with foliar applications of different organic chelates, a mix of nutrients and soil applied NPK under greenhouse conditions. Bars indicate standard deviation. Different letters within each element $(\mathrm{N}$ or $\mathrm{K})$ across all foliar treatments are statistically different $(\mathrm{P}=0.05)$ 
protein biosynthesis. Plants contain $1-5 \% \mathrm{~N}$ in their dry mass (Marschner 2011) and for optimum plant growth and production generally, application of $\mathrm{N}$ fertilizers is required. In the present study, Biomin and DelfonPlus aminochelates with $2-9 \% \mathrm{~N}$ played an important role in supplying plant $\mathrm{N}$ needs. Many studies indicate that there is a positive correlation between shoot $\mathrm{N}$ content and overall plant growth and quality production (Marschner 2011). Furthermore, amino acids have high ability to form chelate with metal nutrient elements (Zhou et al. 2007) and thus, increasing their plant availability. This is more adaptive to sustainable management of fertilization in agricultural systems.

\subsection{Pod yield and related parameters}

Pod yield of green bean plants was improved by fertilizers application (Table 4). Foliar application of DelfonPlus and Biomin aminochelates produced significantly higher pod yield per plant (Table 4). In a similar trend, plant pod number and the length of pods were significantly increased using various fertilizer treatments. Foliar application of three organic-chelates and soil applied NPK resulted in significantly more pods and longer pods in treated plants compared to control. The mix macromicronutrients also resulted in longer pods than control plants. Among fertilizer treatments, foliar application of the macro and micronutrients mixture showed the lowest increase of yield parameters compared to control plants (Table 4).

Increase in plant yield due to application of organic or amino-chelates have been also reported in other studies (Abdul-Qados 2009; Moreira and Moraes 2017; Fahimi et al. 2016; Sadak et al. 2015; Souri et al. 2017). Higher bioavailability of nutrient elements is probably the main factor behind these growth and yield improvements. The role of amino acids in phytohormone biosynthesis
(Marschner 2011), cell membrane stability, and optimization of photosynthesis and metabolism (Keutgen and Pawelzik 2008; Souri 2016) can also play key roles in higher yields achievement by organic chelates application in the present study.

\subsection{Pod quality traits}

Determination of some pod quality traits (Table 4; Figure2; Figure3) showed that pod TSS was significantly higher in plants treated with DelfonPlus and Biomin aminochelates compared to control plants (Table 4).Measuring pod juice $\mathrm{pH}$ revealed that there was no significant difference among various treatments compared to control plants (Table 4). However, there was a significant increase in titratable acidity of pods by fertilizer applications, particularly by organic-chelates. Foliar application of Humifolin showed a significant higher titratable acidity of green pods compared to DelfonPlus and Biomin aminochelates. The lowest titratable acidity was obtained in plants treated with soil application of NPK (Table 4).

Control plants showed the lowest pod vitamin content (Figure2), and application of various fertilizers significantly increased the content of vitamin $\mathrm{C}$ of bean pods. Foliar application of all three organic-chelates have led to significantly higher vitamin $\mathrm{C}$ content of pods compared to soil application of NPK or foliar application of macro and micronutrients mixture. The three organicchelates showed no significant difference regarding pod vitamin C content (Figure2). Similarly, application of various fertilizers, except foliar application of macro and micronutrients mixture, resulted in significantly higher pod protein content compared to control plants (Figure 3); however, the highest protein content was obtained from plants treated with foliar application of DelfonPlus (Figure 3). The improvement in quality of various crops due to application of organic-chelates have been also

Table 4: Mean values ( \pm SD) of yield and pod quality of green bean plants treated with foliar applications of different organic chelates, a mix of nutrients and soil applied NPK under greenhouse conditions. In each column means with at least one common letter are not significantly different $(\mathrm{P}=0.05)$

\begin{tabular}{lllllll}
\hline & $\begin{array}{l}\text { Plant } \\
\text { pod yield (g) }\end{array}$ & $\begin{array}{l}\text { Plant } \\
\text { pod number }\end{array}$ & $\begin{array}{l}\text { Pod length } \\
(\mathbf{c m})\end{array}$ & $\begin{array}{l}\text { Pod TSS } \\
(\%)\end{array}$ & $\begin{array}{l}\text { Pod pH } \\
\text { Pod titratable } \\
\text { acidity (\%) }\end{array}$ & $\begin{array}{l}\text { (\%) } \\
\text { Control }\end{array}$ \\
NPK & $7.3 \pm 0.4^{\mathrm{d}}$ & $4 \pm 0.6^{\mathrm{b}}$ & $4.2 \pm 0.4^{\mathrm{c}}$ & $1.6 \pm 0.2^{\mathrm{b}}$ & $6.20 \pm 0.7^{\mathrm{a}}$ & $30.2 \mathrm{~b} \pm 1.4^{\mathrm{c}}$ \\
Biomin & $14.7 \pm 0.8^{\mathrm{b}}$ & $7 \pm 0.5^{\mathrm{a}}$ & $6.3 \pm 1.1^{\mathrm{a}}$ & $1.8 \pm 0.1^{\mathrm{ab}}$ & $6.34 \pm 0.5^{\mathrm{a}}$ & $25.4 \pm 2.3^{\mathrm{c}}$ \\
Humifolin & $17.3 \pm 1.2^{\mathrm{ab}}$ & $8 \pm 0.8^{\mathrm{a}}$ & $6.8 \pm 0.8^{\mathrm{a}}$ & $2.1 \pm 0.2^{\mathrm{a}}$ & $6.22 \pm 0.4^{\mathrm{a}}$ & $40.5 \pm 4.2^{\mathrm{b}}$ \\
DelfonPlus & $15.8 \pm 0.9^{\mathrm{b}}$ & $7 \pm 0.5^{\mathrm{a}}$ & $6.7 \pm 0.7^{\mathrm{a}}$ & $1.9 \pm 0.3^{\mathrm{a}}$ & $6.25 \pm 0.3^{\mathrm{a}}$ & $48.1 \pm 3.8^{\mathrm{a}}$ \\
Mix macro- micronutrient & $19.4 \pm 0.7^{\mathrm{a}}$ & $8 \pm 0.7^{\mathrm{a}}$ & $7.2 \pm 0.9^{\mathrm{a}}$ & $2.0 \pm 0.4^{\mathrm{a}}$ & $6.25 \pm 0.4^{\mathrm{a}}$ & $35.8 \pm 2.6^{\mathrm{b}}$ \\
\hline
\end{tabular}

- SD indicates standard deviation. 
reported (Keutgen and Pawelzik 2008; Naseri et al. 2013; Ghasemi et al. 2013; Fahimi et al. 2016; Souri et al. 2017). Increasing nutrient uptake (Ghasemi et al. 2012) and internal efficiency (Marschner 2011) might also play a key role in improvement of pod TSS and other quality traits under application of DelfonPlus and Biomin aminochelates. The effects can also be attributed to higher leaf photosynthesis rates and optimization of plant cell metabolism by amino acid-or organic acid- component of used chelates, although the role of micronutrients in these formulations can not be ignored. Micronutrients such as
$\mathrm{Zn}$ and $\mathrm{Mn}$ are key important elements in many enzymatic reactions leading to production of proteins and vitamins (Marschner 2011).

Regarding the superior effect of organic-chelates on plant growth and quality, the role of amino acids seems to be dominant, because in the present study, DelfonPlus, which consisted only of $\mathrm{N}$-amino acids was the most effective among three organic-chelates. In addition, foliar application of macro and micronutrients mixture treatment showed the lowest increase of plant physiological traits. This highlights the role of amino acids

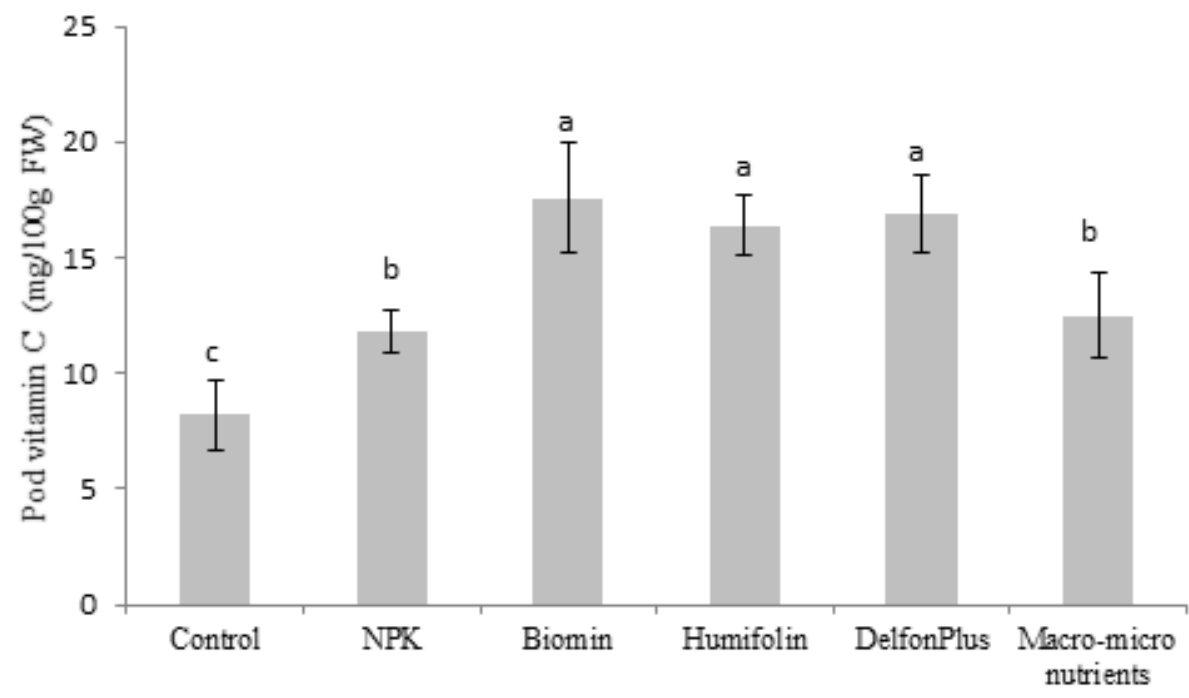

Figure 2: Mean values of pod vitamin C of green bean plants treated with foliar applications of different organic chelates, a mix of nutrients and soil applied NPK under greenhouse conditions. Bars indicate standard deviations. Different letters across all foliar treatments are statistically different $(\mathrm{P}=0.05)$

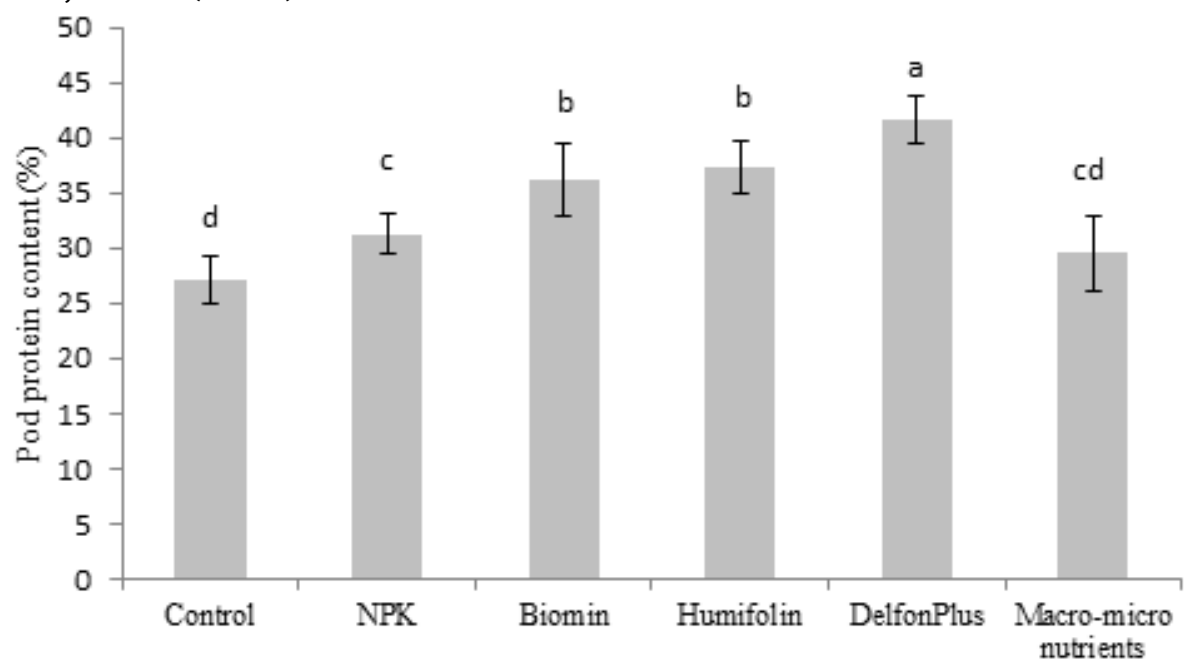

Figure 3: Mean value of pod protein content of green bean plants treated with foliar applications of different organic chelates, a mix of nutrients and soil applied NPK under greenhouse conditions. Bars indicate standard deviations. Different letters across all foliar treatments are statistically different $(P=0.05)$ 
in DelfonPlus and Biomin aminochelates, and the role of organic acid (humic acid) in Humifolin as effective and efficient component. Humic acid is also a natural chelator of nutrients which improves plant growth characteristics in soil or foliar spray (Fahimi et al. 2016). Application of organic chelates particularly aminochelates can significantly ameliorate negative effects of salinity on crop plants (Abdul-Qados 2009; Keutgen and Pawelzik 2008). Effects of exogenous application of some amino acids mainly proline and glycinebetaine on improving plant tolerance to drought has been widely highlighted (Ashraf and Foolad 2007). Therefore, application of sole amino acids or in the form of chelate fertilizers, such as aminochelates and humichelates can have various beneficial effects on nutrient uptake, plant growth and production. They may also play a key role in increasing drought tolerance of agricultural crops.

The organic chelates used in the present study contained one or several components including $\mathrm{N}$ (in form of amino acids and mineral $\mathrm{N}$ ), $\mathrm{Mg}, \mathrm{P}$ and micronutrients such as Fe and $\mathrm{Zn}$ which generally have inevitable role in photosynthesis and plant productivity. They are the key component for those metabolic reactions required for optimum leaf growth and functioning. However, in our study the highest plant growth, yield and quality records were obtained in plants treated with foliar application of DelfonPlus, which contained only about $9 \%$ amino acid-N, but not other nutrients. This indicates that amino acids, as a vital component of aminochelates can have significant effect on plant growth and production (Näsholm et al. 2009). The minor positive effects of foliar application of the macro and micronutrients mixture treatment also support this statement.

\subsection{Conclusion}

In the present study, the growth parameters of green bean plants were improved by foliar application of organicchelate fertilizers, as well as by soil NPK application. There was no difference among the three chelate fertilizers for most traits; however DelphonPlus with only high levels of $\mathrm{N}$-amino acid (without other nutrients) resulted in highest plant growth, yield and pod quality. This highlights the stimulation effect of amino acid on plant growth. Foliar application of the macro and micronutrients mixture was not able to produce the same growth and yield qualities likeorganic-chelate fertilizers. This might suggest that amino acid or humic acid component of these organicchelates is the main effective component in their stimulating effect on plant growth and quality.
Conflict of interest: Authors state no conflict of interest.

\section{References}

Abdul-Qados A.M.S., Effect of arginine on growth, yield and chemical constituents of wheat grown under salinity condition. Acad. J. Plant Sci., 2009, 2, 267-278

Ashmead H.D., Foliar Feeding of Plants with Amino Acid Chelates. Park Ridge: Noyes Publications, 1986

Ashraf M., Foolad M.R., Roles of glycine betaine and proline in improving plant abiotic stress resistance. Envir. Exp. Bot., 2007, 59, 206-216

Atilio J.B., Causin H.F., The central role of amino acids on nitrogen utilization and plant growth. Plant Physiol., 1996, 149(3), 358-362

Bradford M.M., A rapid and sensitive method for the quantitation of microgram quantities of protein utilizing the principle of protein-dye binding. Anal. Biochem., 1976, 72, 248-254

Datir R.B., Apparao B.J., Laware S.L., Application of amino acid chelated micronutrients for enhancing growth and productivity in chili (Capsicum annum L.). Plant Sciences Feed, 2012, 2(7), 100-105

Fahimi F., SouriM.K., Yaghobi F., Growth and development of greenhouse cucumber under foliar application of Biomin and Humifolin fertilizers in comparison to their soil application and NPK. J. Sci. Techn. Greenhouse Cult., 2016, 7, 143-152

Fernández V., Ebert G ., Foliar iron fertilization: a critical review. Plant Nutr., 2005, 28, 2113-2124

Garcia A.L., Madrid R., Gimeno V., Rodriguez-Ortega W.M., Nicolas N., Garcia-Sanchez F., The effects of amino acids fertilization incorporated to the nutrient solution on mineral composition and growth in tomato seedlings. Spanish J. Agri. Res., 2011, 9(3), 852-861

Ghasemi S., Khoshgoftarmanesh A.H., Afyuni M., Hadadzadeh H., The effectiveness of foliar applications of synthesized $\mathrm{Zn}$-amino acid chelates in comparison with $\mathrm{Zn}$ sulfate to increase yield and grain nutritional quality of wheat. Agronomy, 2013, 45, 68-74

Ghasemi S., Khoshgoftarmanesh A.H., Afyuni M., Iron(II)-amino acid chelates alleviate salt-stress induced oxidative damages on tomato grown in nutrient solution culture. Scientia Hort., 2014, 165, 91-98

Ghasemi S., Khoshgoftarmanesh A.H., Hadadzadeh H., Jafari M., Synthesis of iron-amino acid chelates and evaluation of their efficacy as iron source and growth stimulator for tomato in nutrient solution culture. J. Plant Growth Reg., 2012, 31(4), 498-508

Ghoname A.A., El-Bassiouny A.M., Abdel-Mawgoud A.M.R., El-Tohamy W.A., Gruda N., Growth, yield and blossom-end rot incidence in bell pepper as affected by $P$ level and amino acid applications. GesundePflanzen, 2012, 64(1), 29-37

Keutgen A., Pawelzik E., Contribution of amino acids to strawberry fruit quality and their relevance as stress indicators under $\mathrm{NaCl}$ salinity. Food Chem., 2008, 111, 642-647

Machado F., Alves R.E., Fiqueiredo R.W., Application of 1-methylcyclopropene, calcium chloride and calcium amino acid chelate on fresh-cut cantaloupe muskmelon. Pesq. Agropec. Bras., 2008, 43, 569-574. 
Marschner P., Marschner's Mineral Nutrition of Higher Plants, third ed., London, 2011

Moreira A., Moraes L.A.C., Yield, nutritional status and soil fertility cultivated with common bean in response to amino-acids foliar application. J. Plant Nutr., 2017, 40, 344-351

Naseri B., Aboutalebi A., Khademi R., Effects of calcium and micro-nutrients amino chelate on quantity and quality of 'Kabkab'date fruit. Inter. J. Farm and Alli. Sci., 2013, 2, 1302-1306

Näsholm T., Kielland K., Ganeteg U., Uptake of organic nitrogen by plants. New Phytol., 2009, 182, 31-48

Sadak M., Abdoelhamid M.T., Schmidhalter U., Effect of foliar application of aminoacids on plant yield and some physiological parameters in bean plants irrigated with sea water. Acta Biol. Colomb., 2015, 20(1), 141-152
Souri M.K., Aminochelate fertilizers: the new approach to the old problem; a review. Open Agri., 2016, 1(1), 118-123

Souri M.K., Characterization of natural and synthetic nitrification inhibitors and their potential use in tomato culture. Ph. D. dissertation, University of Hohenheim, Stuttgart-Germany, 2008

Souri M.K., YaghoubiSooraki F., Moghadamyar M., Growth and quality of cucumber, tomato, and green bean plants under foliar and soil applications of an aminochelate fertilizer. Hort. Environ. Biotech., 2017, 58(6), 530-536

Zhou Z., Zhou J., Li R., Wang H., Wang J. Effect of exogenous amino acids on $\mathrm{Cu}$ uptake and translocation in maize seedlings. Plant Soil, 2007, 292, 105-117 